\title{
DNA damage alters nuclear mechanics through chromatin reorganisation
}

\author{
Ália dos Santos ${ }^{1}$, Alexander W. Cook ${ }^{1}$, Rosemarie E Gough ${ }^{1}$, Martin Schilling ${ }^{2}$, Nora \\ Aleida Olszok ${ }^{2}$, lan Brown ${ }^{3}$, Lin Wang ${ }^{4}$, Jesse Aaron ${ }^{5}$, Marisa L. Martin-Fernandez ${ }^{4}$, \\ Florian Rehfeldt ${ }^{2,6 *}$ and Christopher P. Toseland ${ }^{1 *}$ \\ ${ }^{1}$ Department of Oncology and Metabolism, University of Sheffield, Sheffield, S10 2RX, UK. ${ }^{2}$ University \\ of Göttingen, 3rd Institute of Physics - Biophysics, Göttingen, 37077, Germany. ${ }^{3}$ School of Biosciences, \\ University of Kent, Canterbury, CT2 7NJ, UK. ${ }^{4}$ Central Laser Facility, Research Complex at Harwell, \\ Science and Technology Facilities Council, Rutherford Appleton Laboratory, Harwell, Didcot, Oxford \\ OX11 OQX, UK. ${ }^{5}$ Advanced Imaging Center, HHMI Janelia Research Campus, Ashburn, USA. \\ ${ }^{6}$ University of Bayreuth, Experimental Physics 1, Bayreuth, 95440, Germany.
}

*Corresponding Authors: Florian Rehfeldt florian.rehfeldt@uni-bayreuth.de \& Christopher P. Toseland c.toseland@sheffield.ac.uk

Key words: Mechanics, DNA damage, DNA organisation, Nucleus

\begin{abstract}
DNA double-strand breaks (DSBs) drive genomic instability. For efficient and accurate repair of these DNA lesions, the cell activates DNA damage repair pathways. However, it remains unknown how these processes may affect the biomechanical properties of the nucleus and what role nuclear mechanics play in DNA damage and repair efficiency.

Here, we used Atomic Force Microscopy (AFM) to investigate nuclear mechanical changes, arising from externally induced DNA damage. We found that nuclear stiffness is significantly reduced after cisplatin treatment, as a consequence of DNA damage signalling. This softening was linked to global chromatin decondensation, which improves molecular diffusion within the organelle. We propose that this can increase recruitment for repair factors. Interestingly, we also found that reduction of nuclear tension, through cytoskeletal relaxation, has a protective role to the cell and reduces accumulation of DNA damage. Overall, these changes protect against further genomic instability and promote DNA repair. We propose that these processes may underpin the development of drug resistance.
\end{abstract}

\section{INTRODUCTION}

Cells are known to respond to external stimuli through changes to their biomechanical properties, such as cellular stiffness. Some studies have previously related chemotherapy treatments to changes in the stiffness of cells and tissues $^{1,2}$. Chemotherapy agents such as cisplatin induce DNA damage, and therefore their main mechanism of action occurs within a nuclear context. However, little is known about the biomechanical changes that might occur in the organelle following DNA damage.
Cisplatin, specifically, creates adducts within the double helix, which then lead to double-strand breaks (DSBs) in the DNA during replication, through replication-fork collapse ${ }^{3}$.

DSBs can result in large genomic aberrations and are, therefore, the most deleterious to the cell. In the event of a DNA break, the cell activates DNA Damage Response (DDR) pathways that allow detection and repair of this lesion. Failure to repair damage leads to cell death through apoptosis, or to the propagation of mutations that drive genomic instability and cancer development 4-6.

It is well known that the ataxia-telangiectasia mutated (ATM) kinase localises to regions of damage, where it phosphorylates histone H2AX, producing $\mathrm{yH} 2 \mathrm{AX}$. This, in turn, promotes the recruitment of multiple repair factors to foci of damage $^{7,8}$. However, it is not yet known if DNA damage, or DDR itself, could lead to alterations in nuclear mechanics.

It is established that chromatin and the lamina are major determinants of nuclear mechanics ${ }^{9}$, and we have previously shown that a thicker nuclear lamina correlate with higher nuclear stiffness ${ }^{10}$. In the context of DDR, local changes to the condensation state of the chromatin are associated to efficiency of DNA repair, and chromatin remodelling factors are known to be recruited to foci of damage ${ }^{11,12}$. As with DNA damage, it is still unknown how these alterations impact the physical properties of the nucleus.

Here, we investigated the relationship between DNA damage and nuclear mechanics. We used Atomic Force Microscopy (AFM) to probe mechanics of the nucleus of mammalian cells and monitor changes that occur after treatment with cisplatin. We found that, following DNA damage, large-scale mechanical alterations to the nucleus arise, caused by global 
decondensation of chromatin. This is dependent on DDR activation and increases molecular diffusion in the nucleus, potentially resulting in higher accessibility for repair factors. Surprisingly, we also found that mechanical relaxation of the nucleus, independently of chromatin, protects against genomic instability. Collectively, our data reveal how changes to chromatin architecture following DNA damage both suppress further genomic instability and provide an environment to promote repair. These findings may be harnessed to promote therapeutic approaches (e.g. resistance within a tumour environment).

\section{RESULTS}

Whilst the biochemical responses to DNA damage are well investigated $4,13,14$, their effects on the biophysical properties of the nucleus are still poorly understood. To investigate this, we used cisplatin, a chemotherapy drug that crosslinks DNA, thereby inducing DSBs within DNA, and AFM to measure mechanical changes in nucleus.

Cisplatin treatment reduces nuclear stiffness. Before AFM measurements, fully-adhered cells on glass were treated with $25 \mu \mathrm{M}$ cisplatin for 4 hours, or 24 hours, which induced DNA damage, recorded as fluorescent foci of $\gamma \mathrm{H} 2 \mathrm{AX}$ (Fig. 1A). AFM measurements were performed at a central point above the nucleus of a selected cell, up to a maximal force of $10 \mathrm{nN}$ (Fig. 1B and C). Forcedistance curves were then fitted using the Hertz model, to determine the effective Young's elastic moduli $E$. Figure 1D shows representative experimental curves of deflection versus probesample separation and, in the insets, the fitted curves.

We found that long treatment with cisplatin (24 hours), but not short treatment (4 hours), significantly reduced cellular stiffness (Fig. 1E). Young's modulus values changed from $4.4 \pm 0.6$ $\mathrm{kPa}$ (mean $\pm \mathrm{SEM}$ ) in non-treated cells to $3.2 \pm$ $0.4 \mathrm{kPa}$ after cisplatin 4-hours and $1.9 \pm 0.2 \mathrm{kPa}$ in cells, following 24-hour cisplatin treatment. These results suggest that the observed mechanical change is temporally separated from the DNA damage itself. Therefore, breaks in DNA do not directly change the mechanical properties of the nucleus, but rather trigger events that further downstream affect the nuclear stability.

Although these measurements were taken at a central point above the nucleus, the complex actin cytoskeleton extends throughout the whole cell and exerts large amounts of force on the nucleus through compression, thus altering its physical properties and potentially masking mechanical changes. As a result, it is difficult to understand what the individual contributions of the nucleus and the cytoskeleton are to wholecell mechanics.

To understand if the mechanical changes observed were a result of alterations to the cytoskeleton, we labelled cells with phalloidin after cisplatin treatment (Supp Fig.1). Our data show that there is no actin cytoskeleton impairment, indicating that the observed mechanical effect is not a result of the dissociation of actin filaments in the cell. We therefore postulated that the change in stiffness could be the result of altered biophysical properties in the nucleus.

To understand the individual contribution of the nucleus to global mechanics, we decided to perform measurements on cells at initial adhesion stages, isolated nuclei (Fig. 2A, Supp Fig 2) and cells treated with two different cytoskeletal destabilizing drugs - Blebbistatin and Latrunculin B (Supp. Fig. 1).

At initial adhesion stages, the nucleus is the largest contributor to whole-cell mechanics. In this case, the cells are given enough time to adhere to the surface (2-3 hours for HeLa cells) but the cytoskeleton and in particular stress fibres, are not fully established (Supp Fig.1). As a result, AFM measurements taken above the nucleus only reflect the mechanical properties of the organelle. Alternatively, Blebbistatin, a Myosin II inhibitor, and Latrunculin B, an actin depolymerising drug, relax the cytoskeleton ${ }^{15-17}$, and therefore measurements in these cells are mainly directed at the nucleus, without a contribution from the cytoskeleton.

Our AFM data show that, as expected, fullyadhered cells $(4.4 \pm 0.7 \mathrm{kPa})$ are stiffer than Latrunculin $B$ and Blebbistatin treated cells $(2.6 \pm 1.2 \mathrm{kPa}$ and $2.1 \pm 0.8 \mathrm{kPa}$, respectively), initially-adhered cells $(2.9 \pm 0.3 \mathrm{kPa})$ and isolated nuclei $(2.6 \pm 0.4 \mathrm{kPa})$, whilst there is no significant difference between these four latter conditions (Fig. 2B).

From these data we confirmed that nuclear measurements performed in initially-adhered cells are relatively free of cytoskeletal contributions and that the nucleus remains as the only large structural variable. Therefore, we decided to use this approach to investigate changes to nuclear mechanics, as this allows for the physical properties of nucleus to be probed whilst maintaining the organelle in its physiological environment and without the use of drugs that may have unknown effects in our study.

To investigate effects of DNA damage in nuclear mechanics, we used $25 \mu \mathrm{M}$ cisplatin treatments for 4 and 24 hours on initially-adhered HeLa cells, which were seeded on glass slides 2 hours before AFM measurements. This revealed that the Young's moduli of nuclei were significantly 
reduced after both 4 hours $(1.6 \pm 0.2 \mathrm{kPa}$, $P<0.001)$ and 24 hours $(1.2 \pm 0.3 \mathrm{kPa}, \mathrm{P}<0.001)$ of cisplatin treatment (Fig. 2C). Surprisingly, we could observe mechanical changes after short cisplatin treatment in initially-adhered cells (Fig. 2C), whilst this was not possible in fully-adhered (Fig. 1C). This suggests that cytoskeletal contributions, present in fully adhered cells may be masking smaller nuclear mechanical changes occurring in shorter treatments.

To confirm that the observed effect is intrinsic to the nucleus, we also performed these measurements on isolated nuclei (Fig. 2A), following 4-hour cisplatin treatment. Immunofluorescence images of isolated nuclei with membrane dye DiD show that the nuclear membrane in isolated nuclei is intact (Supp Fig. 2). As expected, there is a large decrease in Young's moduli values from non-treated nuclei (2. $6 \pm 0.4 \mathrm{kPa})$ to cisplatin-treated $(0.9 \pm 0.2 \mathrm{kPa}$, $\mathrm{P}<0.0001$ ), confirming these changes occur are intrinsic to the nucleus (Fig. 2D).

\section{DNA damage signalling is required for mechanical changes to the nucleus}

As cisplatin treatment causes severe DNA damage, we wondered if these mechanical changes were dependent on DDR signalling. Following DSBs, ATM kinase is recruited to sites of damage, where it phosphorylates histone $\mathrm{H} 2 \mathrm{AX}{ }^{18}$. This results in the recruitment of repair factors to DSBs and biochemical changes that determine the cell's fate f $^{79-21}$.

To investigate this, we inhibited the ATM kinase, using inhibitor KU55933 (iATM) by pre-treating cells with iATM for 30 minutes before 4-hour treatment with $25 \mu \mathrm{M}$ cisplatin (also in the presence of iATM). Immunofluorescence shows that treatment with iATM impairs the formation of yH2AX foci (Fig. 3A). AFM measurements on initially adhered cells (Fig. 3B) show no difference between nuclei of non-treated cells $(2.9 \pm 0.3 \mathrm{kPa})$ and nuclei of cells treated with cisplatin after preincubation with iATM $(2.7 \pm 0.3 \mathrm{kPa})$. Surprisingly, these data suggest that mechanical changes to the nucleus occur after DNA damage response signalling is activated and appears to be dependent on ATM kinase. This confirms that mechanical changes do not arise directly from the induction of the DSBs.

\section{Mechanical changes of the nucleus after DNA damage are caused by chromatin decondensation}

The nuclear lamina is a major structural component of the nucleus. We therefore tested if cisplatin treatment changed lamina integrity, thus changing nuclear mechanics. Our results show that for non-treated and cisplatin-treated cells there are no changes in thickness of the nuclear lamina (Supp. Fig.3A and B). Negative-stain electron microscopy (EM) data support this observation and show that nuclear membrane integrity is not compromised following cisplatin treatments (Supp. Fig. 3C). This suggests that the reduction of the Young's modulus of the nucleus is not a result of a structural compromise to the nuclear lamina.

Together with the lamina, chromatin compaction is one of the other major contributors for nuclear mechanics, and previous studies have suggested that the state of chromatin condensation can change following DSBs ${ }^{12,22-24}$. If this is the case, global changes to chromatin compaction could result in significant alterations to nuclear mechanics.

To investigate this hypothesis, we used EM to image both non-treated and cisplatin-treated cells and compared it to Trichostatin A (TSA), a deacetylase inhibitor that leads to decondensation of chromatin. Dense regions of staining corresponding to condensed chromatin are clearly visible in the non-treated cells. This contrasts with both cisplatin and TSA treated cells (Fig. 4A). Quantification of chromatin compaction from EM images, based on intensity of staining, shows that cells treated with cisplatin have higher levels of decondensed chromatin, similarly to TSA-treated cells, whilst non-treated cells have higher amounts of condensed chromatin (Fig. 4B).

To test if chromatin decondensation, following TSA treatment, had a similar effect to cisplatin on nuclear stiffness, we measured the Young's modulus in nuclei of initially adhered cells. Our AFM data show (Fig. 4C) that nuclei in TSAtreated cells $(1.0 \pm 0.1 \mathrm{kPa})$ are significantly softer than in non-treated cells $(2.9 \pm 0.3)$ and display similar mechanics to long-term cisplatin-treated cells $(1.2 \pm 0.3)$.

To complement EM data and confirm the observed effects of cisplatin on chromatin, we used super-resolution STORM imaging. Standard antibody staining was used to image y $\mathrm{H} 2 \mathrm{AX}$, whilst we took advantage of the photophysical properties of the Hoechst DNA dye to visualise chromatin (Fig. $5 \mathrm{~A}$ and $\mathrm{B}$ ). Qualitatively, our results confirm that chromatin decondensation occurs after cisplatin treatment (Fig. 5A) compared to the non-treated sample, and similarly to TSA-treated cells (Fig. 5B). In the non-treated sample, clearly defined chromatin bundles are present within the nuclear periphery and interior. However, upon cisplatin treatment there are a few islands of condensed DNA but there is loss of the extensive network. The extent of chromatin relaxation in this case is comparative to TSA treatment. Taken together, these results strongly suggest that chromatin decondensation is a determining factor for 
changes in nuclear mechanics after DNA damage.

A possible benefit that arises from chromatin decondensation is that it may allow for higher protein diffusion in the nucleus, thus enabling repair factors to reach areas of damage more easily. To test this, we used Multifocal Microscopy (MFM) ${ }^{25}$ and 3D single-particle tracking to measure the diffusion constants of a fluorescently-labelled SNAP tag ${ }^{26,27}$, expressed in HeLa cells, in treated and non-treated conditions. MFM allows us to do live-cell, singlemolecule imaging across nine simultaneous $\mathrm{z}$ planes (Fig. 5C) ${ }^{25}$, hence creating a comprehensive 3D model of molecular diffusion in nucleus. The SNAP tag was used as a reporter of free diffusion within the nucleus. Figure 5D shows a representative 3D map for single-particle tracking using MFM.

Our data show that the diffusion constant of the SNAP-tag in the nucleus of cells treated with cisplatin $\left(1.2 \pm 0.04 \mu \mathrm{m}^{2} / \mathrm{s}\right)$ is significantly higher than in non-treated cells $\left(0.8 \pm 0.03 \mu \mathrm{m}^{2} / \mathrm{s}\right)$, but similar to TSA-treated $\left(1.3 \pm 0.04 \mu \mathrm{m}^{2} / \mathrm{s}\right)$ (Fig. 5E). This supports the idea that chromatin decondensation following damage allows proteins to diffuse more rapidly within the nucleus.

\section{Mechanical relaxation of the nucleus protects cells from damage}

Recently, studies have linked the occurrence of DNA damage to external forces exerted on the nucleus ${ }^{28,29}$. Similarly, there is some evidence that increased forces on the nucleus exacerbate the extent of DNA damage ${ }^{30,31}$. It is possible that, after DNA damage, a softer nucleus, also leads to a loss of tension on the nucleus which prevents further genomic instability.

To investigate how forces exerted on the nucleus influence DNA damage, we decided to pre-treat cells with Blebbistatin for 30 minutes before 4hour treatment with cisplatin (also in the presence of Blebbistatin). This allowed us to minimise cytoskeletal forces on the nucleus prior to the occurrence of damage. We used $\mathrm{yH} 2 \mathrm{AX}$ as a marker for damage. High-content screening revealed a large decrease in the percentage of damaged cells when they pre-incubated with Blebbistatin. In non-treated cells, only $5.1 \pm 0.2 \%$ of the population showed $\mathrm{yH} 2 \mathrm{AX}$ signalling, as expected. $37.4 \pm 0.9 \%$ of cisplatin-treated cells (short treatment) displayed signs of damage, whilst this value dropped to $21.2 \pm 0.6 \%$ for cells that were pre-incubated with Blebbistatin (Fig. 6A and $B$ ). This suggests that a decrease in forces acting on the nucleus has a protective effect towards DNA damage.

Matrix stiffness is tightly related to cell spread, adhesion formation and cytoskeletal force ${ }^{32-34}$.
As a result, a stiffer surface will create higher forces in the cytoskeleton, which would then translate into higher mechanical constraints to the nucleus ${ }^{35-37}$. To further explore this relationship between stiffness and the extent of DNA damage, we used polyacrylamide gels of different stiffness $(2,11$ and $30 \mathrm{kPa})$ as surfaces for cells (Fig. 7A). The ability of the cells to respond to the gel stiffness is confirmed when we measure the cross-sectional area of the nucleus. Here, the greater tension exerted by the stiffer gel matrix leads to an increase in nuclear area from $291.0 \pm 8.5 \mu \mathrm{m}^{2}$ to $456.0 \pm 10.8 \mu \mathrm{m}^{2}$ (Fig. 7B), in line with earlier findings ${ }^{38}$.

If we expect lower force to have a protective effect, lower surface stiffness should decrease the amount of damage in cells, in a similar way to Blebbistatin treatment. As expected, our data reveal that cells treated in stiffer gels, $30 \mathrm{kPa}$, have $65 \%$ higher levels of $\mathrm{yH} 2 \mathrm{AX}$ levels compared to $2 \mathrm{kPa}$ gels and $30 \%$ higher than 11 $\mathrm{kPa}$ gels (Fig. 7C). Overall, less tension across the nucleus leads to less damage.

\section{DISCUSSION}

Our work reveals a direct link between DNA damage, chromatin condensation and nuclear mechanics. It has been shown that treatment with cisplatin and other chemotherapy drugs changes whole-cell mechanics ${ }^{39,40}$. However, since most studies focus on cytoskeletal contributions, until now it remained unclear how these DNA damage-causing drugs alter the biomechanical properties of the nucleus. Here, by performing AFM measurements in initially adhered cells, we were able to probe the mechanical properties of the nucleus within its cellular environment. Our work shows that cisplatin treatment causes significant alterations to the state of chromatin condensation, which in turn results in a reduction of nuclear stiffness.

Mechanical changes to the nucleus do not arise spontaneously from breaks in the chromatin fibre, but are a result of downstream large-scale chromatin decondensation. The ATM kinase is an essential DSB repair factor that initiates DDR signalling, and its absence or inactivity can lead to a proportion of unrepaired DSBs in the cell ${ }^{41,42}$. Interestingly, the mechanical softening of the nucleus also appears to be coupled to the activity of the ATM kinase, suggesting that chromatin decondensation occurs as a result of the DDR. Several studies have reported localised chromatin decondensation around areas of damage and this is thought to lead to higher repair efficiency $22,23,43$. Our data largely agree with this observation, but we cannot exclude that there are patches of condensed DNA around the damage sites. Moreover, we show that chromatin decondensation, following DNA damage, 
increases molecular diffusion within the nucleus. By creating greater exposure to DNA binding sites and enabling repair factors to readily reach sites of damage, chromatin decondensation could act as a major determinant for the outcome of repair events.

Interestingly, we found that alterations to biomechanics also appear to protect the cell from genomic instability. In addition to the intrinsic mechanical properties of the nucleus, the cytoskeleton also has a large impact on overall nuclear mechanics. Relaxation of the cytoskeleton results in reduced nuclear tension and, here, we show that this has a protective effect in DNA damage. It has been shown that reduction in matrix stiffness, a major determining factor for cytoskeletal organisation, correlates with inhibition of replication ${ }^{44-46}$. Cisplatininduced DSBs require active DNA replication. It is, therefore, possible that the lower levels of DSBs detected in nuclei under lower mechanical tension are a result of altered DNA replication levels. We suggest that a decrease in nuclear stiffness would also destabilise cytoskeletonnuclear linkage which could result in a change in nuclear tension. Our findings agree with the recent findings of Nava et al, which showed that nuclear softening protects against mechanically induced DNA damage ${ }^{30}$. Overall, it appears that the nucleus has an innate ability to protect against different agents.

Deformations to the nuclear envelope, as well as mechanical forces acting on the organelle are important for the regulation of cell cycle progression ${ }^{47}$ and transcription activity 48 . Interestingly, DNA damage leads to cell cycle arrest and transcriptional repression to promote repair. Therefore, DNA damage-induced changes to the mechanosensing properties of the nucleus could contribute to the regulation of these processes. In terms of cell cancer, during migration and invasion, altered nuclear mechanics may be an important factor. For example, whilst travelling through confined spaces, cells with softer nuclei could migrate more easily and with less DNA damage, induced by rupture events resulting from nuclear compression. In this case, a softer nucleus would, once again, protect from further damage. There is growing evidence that tumorigenesis and resistance to chemotherapy agents correlate with changes in cellular and nuclear mechanics 49. Depending on the cell types and type of treatment, drug resistance has been associated with an increase or decrease in cell stiffness ${ }^{49,50}$. Interestingly, there are also possible differences between in vitro cell lines and patient-derived primary samples, where the latter are more deformable. Our data fit with these scenarios, whereby decreased nuclear stiffness promotes repair and prevents further damage, which could subsequently drive drug resistance.

In summary, here, we describe how nuclear mechanics change due to induced DNA damage through chromatin remodelling events, as part of DDR. Furthermore, we show that nuclear envelope relaxation protects against further damage. It will be of interest, in the future, to determine the molecular mechanisms through which nuclear mechanics directly influence DNA damage levels as these pathways may directly influence therapeutic resistance.

\section{ACKNOWLEDGEMENTS}

We thank the UKRI-MRC (MR/M020606/1), UKRISTFC (19130001) and the Royal Society (IE170270) for funding to C.P.T. Aberration-corrected multi-focal microscopy was performed in collaboration with the Advanced Imaging Center at Janelia Research Campus, a facility jointly supported by the Howard Hughes Medical Institute and the Gordon and Betty Moore Foundation. We also thank Satya Khuon (Janelia Research Campus) for assisting with cell culture and Thomas Helleday for sharing equipment. The JF549 dye was kindly provided by Luke Lavis (Janelia Research Campus).

\section{AUTHOR CONTRIBUTIONS}

C.P.T. and F.R. conceived the study. A.dS., F.R. and C.P.T. designed experiments. A.dS. performed AFM measurements with support from M.S. and N.A.O. A.W.C. and R.E.G. performed experiments using the acrylamide gels. I.B. prepared and collected electron microscopy data. A.dS. and C.P.T. performed single molecule imaging experiments. Imaging was supported by L.W., M.L.M-F. and J.A. L.W., J.A., A.dS. and C.P.T. contributed to single molecule data analysis. C.P.T. and F.R. supervised the study. A.dS., C.P.T. and F.R. wrote the manuscript with comments from all authors.

\section{MATERIALS AND METHODS}

\section{Drug Treatments}

Cisplatin [cis-diammineplatinum(II) dichloride] (Sigma) was resuspended in a $0.9 \% \mathrm{NaCl}$ solution to a concentration of $3.3 \mathrm{mM}$, following manufacturer's instructions, and used at a concentration of $25 \mu \mathrm{M}$. Trichostatin A (Sigma) was resuspended to 6.6. $\mathrm{mM}$ in DMSO and used at 400nM in culturing medium, for 24 hours. ATM inhibitor, KU55933 (Sigma), was resuspended in DMSO to $12.6 \mathrm{mM}$ and used at a concentration of $20 \mu \mathrm{M}, 30$ minutes prior treatment and then for the whole duration of cisplatin treatment in culturing medium. Blebbistatin (Sigma) was resuspended to $50 \mathrm{mM}$ in DMSO and used at a concentration of $50 \mu \mathrm{M}$ for 1-2 hours before AFM measurements and for 30 minutes, prior treatment and then the whole duration of cisplatin treatment for imaging. Latrunculin B (Sigma) was resuspended in DMSO to a concentration of $12.6 \mathrm{mM}$ and used at $1 \mu \mathrm{M}$ for 1 hour before AFM measurements.

\section{Cell Culture and Transfection}


HeLa cells (ECACC 93021013) were cultured at $37^{\circ} \mathrm{C}$ and $5 \% \mathrm{CO}_{2}$ in MEM Alpha medium with GlutaMAX, supplemented with $10 \%$ fetal bovine serum (Gibco) and $1 \%$ penicillin/streptomycin (Gibco). HeLa cells were transfected with $0.5 \mu \mathrm{g}$ pSNAPf-C1 plasmid (Addgene 58186) using Lipofectamine 2000 (Invitrogen) and following manufacturer's instructions.

\section{Nuclear Isolation}

Nuclei were prepared based on protocols in ${ }^{10,51}$ HeLa cells were washed with cold PBS, then washed in cold Hypotonic Buffer $\mathrm{N}$ - $10 \mathrm{mM}$ Hepes $\mathrm{pH} 7.5,2 \mathrm{mM}$ $\mathrm{MgCl}_{2}, 25 \mathrm{mM} \mathrm{KCl}, 1 \mathrm{mM}$ PMSF, $1 \mathrm{mM}$ DTT and Protease Inhibitor Cocktail (Thermo Fisher Scientific). Cells were then re-suspended in cold hypotonic buffer $\mathrm{N}$ and incubated for 1 hour on ice. Cells were homogenised on ice, using a glass Dounce homogeniser (Wheaton). Sucrose was added to the cell lysate to a final concentration of $220 \mathrm{mM}$ and mixed well by inversion before centrifugation. The pellet, corresponding to isolated nuclei, was washed in cold Buffer N - $10 \mathrm{mM}$ Hepes pH 7.5, $2 \mathrm{mM} \mathrm{MgCl} 2,25 \mathrm{mM}$ $\mathrm{KCl}, 250 \mathrm{mM}$ sucrose, $1 \mathrm{mM}$ PMSF, $1 \mathrm{mM}$ DTT Protease Inhibitor Cocktail. The nuclei pellet was resuspended in PBS and used immediately for AFM measurements.

\section{Immunofluorescence}

HeLa cells grown on glass coverslips were incubated for 10 minutes at $37^{\circ} \mathrm{C}$ and $5 \% \mathrm{CO}_{2}$ with $1 \mu \mathrm{g} \mathrm{mL}-1$ Hoechst 33342 in growth medium. Stained cells were fixed in $4 \%(\mathrm{~m} / \mathrm{V})$ paraformaldehyde (PFA). Residual PFA was quenched with $50 \mathrm{mM}$ ammonium chloride for 15 minutes at room temperature. Cells were then permeabilised and blocked for 15 minutes with $0.1 \%$ (V/V) Triton X-100 and $2 \%(\mathrm{~m} / \mathrm{V})$ BSA in TBS. Antibodies were used as follows: mouse-Phospho$\mathrm{H} 2 \mathrm{AX}$ (Merck 05-636) at 1:500 dilution, rabbit-Lamin B1 (Abcam ab16048) at a dilution of 1:200, donkey anti-mouse Alexa Fluor 488-conjugated (Abcam Ab181289) at 1:500 and donkey anti-rabbit Alexa Fluor-488-conjugated (Abcam, Ab181346) at 1:500 dilution. For actin staining, fixed and permeabilised cells were stained prior to immunofluorescence with $165 \mathrm{nM}$ Rhodamine-Phalloidin (ThermoFisher) for 20 min. Coverslips were mounted on microscope slides with $10 \%(\mathrm{~m} / \mathrm{V})$ Mowiol, $25 \%(\mathrm{~m} / \mathrm{V})$ glycerol, $0.2 \mathrm{M}$ Tris$\mathrm{HCl}, \mathrm{pH} 8.5$, supplemented with $2.5 \%(\mathrm{~m} / \mathrm{V})$ of DABCO (Sigma).

\section{Fluorescence Imaging}

Cells were visualised using Wide-field microscope Olympus IXT1, or Confocal microscope LSM 880. For confocal microscopy, a Plan-Apochromat 63x 1.4 NA oil immersion lens (Carl Zeiss, 420782-9900-000) was used. Three laser lines: $405 \mathrm{~nm}, 488 \mathrm{~nm}$ and $561 \mathrm{~nm}$, were used to excite Hoechst, Alexa 488 and Alexa 647 fluorophores, respectively. Built-in dichroic mirrors (Carl Zeiss, MBS-405, MBS-488 and MBS-561) were used to reflect the excitation laser beams onto cell samples. For fluorescence collection, the used emission spectral bands were: $410 \mathrm{~nm}-524 \mathrm{~nm}$ (Hoechst), $493 \mathrm{~nm}-578 \mathrm{~nm}$ (Alexa 488) and $564 \mathrm{~nm}$ $697 \mathrm{~nm}$ (Alexa 647). The green channel (Alexa 488) was imaged using a 1 gallium arsenide phosphide (GaAsP) detector, while the blue (Hoechst) and red (Alexa 647) channels were imaged using two multi- anode photomultiplier tubes (MA-PMTs). For imaging acquisition and rendering, ZEN software was used. Confocal Images were deconvolved using the Zeiss Zen2.3 Blue software, using the regularised inverse filter method.

For Wide-field microscopy, a PlanApo 100xOTIRFMSP 1.49 NA lens mounted on a PIFOC z-axis focus drive (Physik Instrumente, Karlsruhe, Germany) was used, with an automated $300 \mathrm{~W}$ Xenon light source (Sutter, Novato, CA) with appropriate filters (Chroma, Bellows Falls, VT). QuantEM (Photometrics) EMCCD camera, controlled by the Metamorph software (Molecular Devices) was used for image acquisition. All images were then analysed by ImageJ.

\section{STORM Imaging}

Cells were seeded on pre-cleaned No 1.5, 25-mm round glass coverslips, placed in 6-well cell culture dishes. Glass coverslips were cleaned by incubating them for 3 hours, in etch solution, made of 5:1:1 ratio of $\mathrm{H}_{2} \mathrm{O}: \mathrm{H}_{2} \mathrm{O}_{2}$ (50 wt. \% in $\mathrm{H}_{2} \mathrm{O}$, stabilized, Fisher Scientific) : $\mathrm{NH}_{4} \mathrm{OH}$ (ACS reagent, 28-30\% $\mathrm{NH}_{3}$ basis, Sigma), placed in a $70^{\circ} \mathrm{C}$ water bath. Cleaned coverslips were repeatedly washed in filtered water and then ethanol, dried and used for cell seeding. Transfected or non-transfected cells were incubated with $1 \mu \mathrm{g} \mathrm{mL} \mathrm{m}^{-1}$ Hoechst 33342 in growth medium for 15 minutes at $37^{\circ} \mathrm{C}, 5 \% \mathrm{CO}_{2}$. Following this, cells were washed with PBS and fixed in pre-warmed $4 \%(\mathrm{w} / \mathrm{v})$ PFA in PBS and residual PFA was quenched for 15 min with $50 \mathrm{mM}$ ammonium chloride in PBS. Immunofluorescence (IF) was performed in filtered sterilised PBS, unless when anti-phospho antibodies were used. Then, IF was performed in filtered sterilised TBS. Cells were permeabilized and simultaneously blocked for $30 \mathrm{~min}$ with $3 \%(\mathrm{w} / \mathrm{v})$ BSA in PBS or TBS, supplemented with $0.1 \%(\mathrm{v} / \mathrm{v})$ Triton X-100. Permeabilized cells were incubated for $1 \mathrm{~h}$ with the primary antibody and subsequently the appropriate fluorophore-conjugated secondary antibody, at the desired dilution in 3\% (w/v) BSA, 0.1\% (v/v) Triton X100 in PBS or TBS. The antibody dilutions used were the same as for the normal IF protocol (see above), except from the secondary antibodies which were used at 1:250 dilution. Following incubation with both primary and secondary antibodies, cells were washed 3 times, for $10 \mathrm{~min}$ per wash, with $0.2 \%$ (w/v) BSA, $0.05 \%(\mathrm{v} / \mathrm{v})$ Triton X-100 in PBS or TBS. Cells were further washed in PBS and fixed for a second time with pre-warmed $4 \%(\mathrm{w} / \mathrm{v})$ PFA in PBS for $10 \mathrm{~min}$. Cells were washed in PBS and stored at $4{ }^{\circ} \mathrm{C}$, in the dark, in $0.02 \%$ NaN3 in PBS, before proceeding to STORM imaging.

Before imaging, coverslips were assembled into the Attofluor ${ }^{\circledR}$ cell chambers (Invitrogen). Imaging was performed in freshly made STORM buffer consisting of $10 \%(\mathrm{w} / \mathrm{v})$ glucose, $10 \mathrm{mM} \mathrm{NaCl}, 50 \mathrm{mM}$ Tris - $\mathrm{pH} 8.0$, supplemented with $0.1 \%(\mathrm{v} / \mathrm{v})$ 2-mercaptoethanol and $0.1 \%(\mathrm{v} / \mathrm{v})$ pre-made GLOX solution which was stored at $4{ }^{\circ} \mathrm{C}$ for up to a week $(5.6 \%(\mathrm{w} / \mathrm{v})$ glucose oxidase and $3.4 \mathrm{mg} / \mathrm{ml}$ catalase in $50 \mathrm{mM} \mathrm{NaCl}, 10 \mathrm{mM}$ Tris $\mathrm{pH}$ 8.0). All chemicals were purchased from Sigma. Imaging was undertaken using the Zeiss Elyra PS.1 system. Illumination was from a HR Diode $642 \mathrm{~nm}$ (150 $\mathrm{mW})$ and HR Diode $488 \mathrm{~nm}(100 \mathrm{~mW})$ lasers where power density on the sample was $7-14 \mathrm{~kW} / \mathrm{cm}^{2}$ and 7 $12 \mathrm{~kW} / \mathrm{cm}^{2}$, respectively 
Imaging was performed under highly inclined and laminated optical (HILO) illumination to reduce the background fluorescence with a 100x NA 1.46 oil immersion objective lens (Zeiss alpha PlanApochromat) with a BP 420-480/BP495-550/LP 650 filter. The final image was projected on an Andor iXon EMCCD camera with $25 \mathrm{msec}$ exposure for 20000 frames for $\gamma \mathrm{H} 2 \mathrm{AX}$ and $60 \mathrm{msec}$ for 60000 frames for Hoechst imaging.

Image processing was performed using the Zeiss Zen software. Where required, two channel images were aligned following a calibration using pre-mounted MultiSpec bead sample (Carl Zeiss, 2076-515). The channel alignment was then performed in the Zeiss Zen software using the Affine method to account for lateral, tilting and stretching between the channels. The calibration was performed during each day of measurements.

The images were then processed through our STORM analysis pipeline using the Zen software. Single molecule detection and localisation was performed using a 9-pixel mask with a signal to noise ratio of 6 in the "Peak finder" settings while applying the "Account for overlap" function. This function allows multi-object fitting to localise molecules within a dense environment. Molecules were then localised by fitting to a 2D Gaussian.

The render was then subjected to model-based crosscorrelation drift correction. The final render was then generated at $10 \mathrm{~nm} /$ pixel and displayed in Gauss mode where each localisation is presented as a $2 \mathrm{D}$ gaussian with a standard deviation based on its precision.

\section{High-Content Screening}

HeLa cells were seeded in clear-bottom, black-walled 96-wellplates at 10000 cells/well in culturing medium and incubated overnight at $37^{\circ} \mathrm{C}, 5 \% \quad \mathrm{CO}_{2}$. For Blebbistatin pre-treated cells, $50 \mu \mathrm{M}$ Blebbistatin was added prior to 4-hour incubation with $50 \mu \mathrm{M}$ Blebbistatin and $25 \mu \mathrm{M}$ cisplatin. For cisplatin-treated cells, only cisplatin was added at $25 \mu \mathrm{M}$ for 4 hours. Cells were then incubated for 15 minutes with Hoechst dye, at $37^{\circ} \mathrm{C}, 5 \% \mathrm{CO}_{2}$ and fixed using $4 \%(\mathrm{~m} / \mathrm{v})$ PFA. Cells were stained with $165 \mathrm{nM}$ Rhodamine-Phalloidin (ThermoFisher) for $20 \mathrm{~min}$ and 1:500 dilution of mousePhospho-H2AX (Merck 05-636) antibody for 1 hour, following the immunofluorescence protocol. Highcontent imaging was undertaken using a Cell Discoverer 7 (Zeiss), using a Plan-Apochromat 20x 0.7 NA objective. Hoechst, Alexa 488 and Rhodamine fluorophores were excited using LED light at wavelengths 385,470 and $567 \mathrm{~nm}$, respectively. ZEN software was used for image acquisition and images were analysed using Zeiss Zen2.3 Blue software.

Multi-focal Imaging and Particle Tracking Analysis Cells were transfected for 24 hours with $0.5 \mu \mathrm{g}$ of pSNAP ${ }_{f}-\mathrm{C} 1$ (Addgene 58186) construct with Lipofectamine 2000 (Invitrogen), according to manufacturer's instructions. Following this, cells were treated with $25 \mu \mathrm{M}$ cisplatin or $400 \mathrm{nM}$ TSA in growth medium for 24 hours.

Cells transiently expressing pSNAP $\mathrm{P}_{\mathrm{f}} \mathrm{C} 1$ construct were labelled for 15 min with $10 \mathrm{nM}$ SNAP-tag-JF549 ligand, in cell culture medium at $37^{\circ} \mathrm{C}, 5 \% \mathrm{CO}_{2}$. Cells were washed for 3 times with warm cell culture medium and then incubated for further $30 \mathrm{~min}$ at $37^{\circ} \mathrm{C}, 5 \% \mathrm{CO}_{2}$.
Cells were then washed three times in pre-warmed FluoroBrite DMEM imaging medium (ThermoFisher Scientific), before proceeding to imaging.

Single molecule imaging was performed using an aberration-corrected multifocal microscope (acMFM), as described by Abrahamsson et al. ${ }^{25}$. Briefly, samples were imaged using $561 \mathrm{~nm}$ laser excitation, with typical irradiance of $4-6 \mathrm{~kW} / \mathrm{cm}^{2}$ at the back aperture of a Nikon 100x 1.4 NA objective. Images were relayed through a custom optical system appended to the detection path of a Nikon Ti microscope with focus stabilization. The acMFM detection path includes a diffractive multifocal grating in a conjugate pupil plane, a chromatic correction grating to reverse the effects of spectral dispersion, and a nine-faceted prism, followed by a final imaging lens.

The acMFM produces nine simultaneous, separated images, each representing successive focal planes in the sample, with ca. $20 \mu \mathrm{m}$ field of view and nominal axial separation of ca. $400 \mathrm{~nm}$ between them. The nine-image array is digitized via an electron multiplying charge coupled device (EMCCD) camera (iXon Du897, Andor) at up to $32 \mathrm{~ms}$ temporal resolution, with typical durations of 30 seconds.

$3 \mathrm{D}+\mathrm{t}$ images of single molecules were reconstructed via a calibration procedure, implemented in Matlab (MathWorks), that calculates and accounts for (1) the inter-plane spacing, (2) affine transformation to correctly align each focal plane in the xy plane with respect to each other, and (3) slight variations in detection efficiency in each plane, typically less than $\pm 5-15 \%$ from the mean.

Reconstructed data were then subject to preprocessing, including background subtraction, mild deconvolution (3-5 Richardson-Lucy iterations), and/or Gaussian de-noising prior to 3D particle tracking using the MOSAIC software suite ${ }^{52}$. Parameters were set where maximum particle displacement was $400 \mathrm{~nm}$ and a minimum of 10 frames was required. Tracks were reconstructed, and diffusion constants were extracted via MSD analysis ${ }^{53}$ using custom Matlab software assuming an anomalous diffusion model.

\section{Atomic Force microscopy}

Atomic Force microscopy (AFM) measurements were performed with an MFP 3D BIO (Asylum Research, Oxford Instruments, Santa Barbara, USA) on top of an inverted fluorescence microscope (IX71, Nikon Instruments, Japan). The combined instrument is mounted on a Halcyonics vibration isolation table (Accurion $\mathrm{GmbH}$, Göttingen, Germany) inside an acoustic enclosure (Asylum Research) to minimize noise. Force-indentation curves were executed in contact mode using the longer triangular cantilever of a TR 400 PB chip that has a pyramidal tip with an opening angle of $35^{\circ}$. The spring constant was determined with the built-in macro based on the thermal method and was in the range $\left(28-31 \mathrm{pN} \mathrm{nm}^{-1}\right)$ and therefore slightly stiffer than the nominal stiffness of $0.02 \mathrm{Nm}^{-1}$. The nucleus was probed on several locations using the ForceMap macro with a maximum indentation force of $1.5 \mathrm{nN}$ and the resulting forceindentation curves were analysed using a modified Hertz model within a self-written IGOR macro as described earlier ${ }^{54,55}$. 
bioRxiv preprint doi: https://doi.org/10.1101/2020.07.10.197517; this version posted July 11 , 2020. The copyright holder for this preprint (which was not certified by peer review) is the author/funder, who has granted bioRxiv a license to display the preprint in perpetuity. It is made available under aCC-BY-NC-ND 4.0 International license.

\section{Polyacrylamide gels}

Elastic polyacrylamide (PA) gels were prepared as described earlier ${ }^{34,55}$. In brief, mixtures for the desired elasticities were prepared using solutions of $40 \%$ acrylamide (\#161-0140, Bio-Rad, Munich, Germany) and $2 \%$ bis-acrylamide (\#161-0142, Bio-Rad, Munich, Germany) in PBS that are stored at $4^{\circ} \mathrm{C}$ for a maximum time of 2 months. These mixtures were polymerized through addition of $1 \%(\mathrm{v} / \mathrm{v})$ ammoniumpersulfate and $0.1 \%(\mathrm{v} / \mathrm{v}) \mathrm{N}, \mathrm{N}, \mathrm{N}, \mathrm{N}$-tetramethylethylenediamine onto freshly plasma-cleaned cover slips that were treated with 3-aminopropyltriethoxysilane (Sigma, Munich, Germany, A3648) and subsequently with a $0.05 \%$ glutaraldehyde solution (Sigma, Munich, Germany, G7651) for firm attachment of the gels. For $25 \mathrm{~mm}$ coverslips, $35 \mu \mathrm{L}$ of the PA gel solution was dispensed and covered with a square superhydrophobic cover glass to equally distribute the solution. Gels were polymerized for 60 min using a plastic box to keep them in a saturated water atmosphere to avoid evaporation. For quality control the Young's elastic modulus $E$ was regularly measured with a bulk rheometer (MCR-501, Anton Paar, Austria) using a $2^{\circ}$ cone and plate geometry. To facilitate cell attachment, the gels were functionalized with rat tail Collagen type I $(0.2 \mathrm{mg} / \mathrm{mL}$ Corning, New York, New York, \#354236) overnight at $4^{\circ} \mathrm{C}$ using the heterobifunctional crosslinker Sulfo-SANPAH (Thermo Scientific, Waltham, Massachusetts, 22,589; $0.4 \mathrm{mM}$ in $50 \mathrm{mM}$ HEPES buffer at $\mathrm{pH} 8)$ active with UV light $(\lambda=365$ $\mathrm{nm}$ ) for $10 \mathrm{~min}$

\section{Electron Microscopy}

Cells attached to Aclar membrane (Agar Scientific) were fixed for $2 \mathrm{~h}$ in $2.5 \%$ glutaraldehyde $(\mathrm{w} / \mathrm{v})$ in 100 $\mathrm{mM}$ sodium cacodylate (CAB) buffer $\mathrm{pH}$ 7.2. Samples were washed twice for $10 \mathrm{~min}$ in $100 \mathrm{mM} \mathrm{CAB}$ and then post-fixed in $1 \%$ osmium tetroxide (w/v) in $100 \mathrm{mM}$ $\mathrm{CAB}$ for $1 \mathrm{~h}$ before being dehydrated using an ethanol series of $50 \%, 70 \%, 90 \%(\mathrm{v} / \mathrm{v})$ and 3 times with $100 \%$ ethanol for 10 minutes per step. The samples were then placed into propylene oxide, for (2x)10 min, and following this into a 1:1 mixture of propylene oxide and Agar LV resin (Agar Scientific) for $30 \mathrm{~min}$. Following this, samples were embedded in freshly prepared Agar $\mathrm{LV}$ resin twice for $2 \mathrm{~h}$ before being placed in shallow aluminium moulds with the cells facing up and were polymerized at $60^{\circ} \mathrm{C}$ for 24 hours before being examined with a dissecting microscope to identify areas confluent with cells. These areas were cut out with a jig saw and attached to polymerized resin blocks with superglue, and once attached, the Aclar membrane was peeled off, exposing a monolayer of cells in the block face. Sections of $70 \mathrm{~nm}$ were cut on a Leica EM UC7 ultramicrotome using a diamond knife (Diatome) and were collected on 400 mesh copper grids. Sections were counterstained in $4.5 \%$ uranyl acetate $(\mathrm{w} / \mathrm{v})$ in $1 \%$ acetic acid $(\mathrm{v} / \mathrm{v})$ for $45 \mathrm{~min}$ and in Reynolds' lead citrate for $7 \mathrm{~min}$. Samples were viewed in a Jeol 1230 transmission electron microscope and images were captured with a Gatan One View $16 \mathrm{mp}$ camera.

\section{Data Availability}

The data supporting the findings of this study are available from the corresponding author on request.

\section{COMPETING INTERESTS}

The authors declare no competing financial interests.

\section{REFERENCES}

1 Lam, W. A., Rosenbluth, M. J. \& Fletcher, D. A. Chemotherapy exposure increases leukemia cell stiffness. Blood 109, 3505-3508, doi:10.1182/blood-2006-08-043570 \%J Blood (2006).

2 Sharma, S. et al. Correlative nanomechanical profiling with super-resolution F-actin imaging reveals novel insights into mechanisms of cisplatin resistance in ovarian cancer cells. Nanomedicine $\quad 8, \quad 757-766$, doi:10.1016/j.nano.2011.09.015 (2012).

3 Frankenberg-Schwager, M. et al. Cisplatinmediated DNA double-strand breaks in replicating but not in quiescent cells of the yeast Saccharomyces cerevisiae. Toxicology 212, 175184, doi:10.1016/j.tox.2005.04.015 (2005).

4 Jackson, S. P. \& Bartek, J. The DNA-damage response in human biology and disease. Nature 461, 1071-1078, doi:10.1038/nature08467 (2009).

5 Surova, O. \& Zhivotovsky, B. Various modes of cell death induced by DNA damage. Oncogene 32, 3789-3797, doi:10.1038/onc.2012.556 (2013).

6 Torgovnick, A. \& Schumacher, B. DNA repair mechanisms in cancer development and therapy. 6, doi:10.3389/fgene.2015.00157 (2015).

7 Paull, T. T. et al. A critical role for histone $\mathrm{H} 2 \mathrm{AX}$ in recruitment of repair factors to nuclear foci after DNA damage. Curr Biol 10, 886-895, doi:10.1016/s0960-9822(00)00610-2 (2000).

8 Polo, S. E. \& Jackson, S. P. Dynamics of DNA damage response proteins at DNA breaks: a focus on protein modifications. 25, 409-433, doi:10.1101/gad.2021311 (2011).

9 Stephens, A. D., Banigan, E. J., Adam, S. A., Goldman, R. D. \& Marko, J. F. Chromatin and lamin A determine two different mechanical response regimes of the cell nucleus. Mol Biol Cell 28, 1984-1996, doi:10.1091/mbc.E16-09-0653 (2017).

10 Lherbette, M. et al. Atomic Force Microscopy micro-rheology reveals large structural inhomogeneities in single cell-nuclei. Scientific Reports 7, 8116, doi:10.1038/s41598-017-085176 (2017).

11 Chai, B., Huang, J., Cairns, B. R. \& Laurent, B. C. Distinct roles for the RSC and Swi/Snf ATPdependent chromatin remodelers in DNA doublestrand break repair. 19, 1656-1661, doi:10.1101/gad.1273105 (2005)

12 Ziv, Y. et al. Chromatin relaxation in response to DNA double-strand breaks is modulated by a novel ATM- and KAP-1 dependent pathway. Nature Cell Biology 8, 870-876, doi:10.1038/ncb1446 (2006).

13 Turgeon, M.-O., Perry, N. J. S. \& Poulogiannis, G. DNA Damage, Repair, and Cancer Metabolism. 8, doi:10.3389/fonc.2018.00015 (2018). 
Scully, R., Panday, A., Elango, R. \& Willis, N. A. DNA double-strand break repair-pathway choice in somatic mammalian cells. Nature Reviews Molecular Cell Biology 20, 698-714, doi:10.1038/s41580-019-0152-0 (2019).

Kovács, M., Tóth, J., Hetényi, C., MálnásiCsizmadia, A. \& Sellers, J. R. Mechanism of Blebbistatin Inhibition of Myosin II. 279, 3555735563, doi:10.1074/jbc.M405319200 (2004). Wakatsuki, T., Schwab, B., Thompson, N. C. \& Elson, E. L. Effects of cytochalasin $D$ and latrunculin B on mechanical properties of cells. Journal of Cell Science 114, 1025 (2001).

17 Spector, I., Shochet, N. R., Blasberger, D. \& Kashman, Y. Latrunculins--novel marine macrolides that disrupt microfilament organization and affect cell growth: I. Comparison with cytochalasin D. Cell Motil Cytoskeleton 13, 127-144, doi:10.1002/cm.970130302 (1989).

18 Burma, S., Chen, B. P., Murphy, M., Kurimasa, A. \& Chen, D. J. ATM Phosphorylates Histone H2AX in Response to DNA Double-strand Breaks. 276, 42462-42467, doi:10.1074/jbc.C100466200 (2001).

Fragkos, M., Jurvansuu, J. \& Beard, P. H2AX Is Required for Cell Cycle Arrest via the p53/p21 Pathway. Molecular and Cellular Biology 29, 2828, doi:10.1128/MCB.01830-08 (2009).

20 Nakamura, A. J., Rao, V. A., Pommier, Y. \& Bonner, W. M. The complexity of phosphorylated H2AX foci formation and DNA repair assembly at DNA double-strand breaks. Cell Cycle 9, 389-397, doi:10.4161/cc.9.2.10475 (2010).

21 Stucki, M. et al. MDC1 Directly Binds Phosphorylated Histone H2AX to Regulate Cellular Responses to DNA Double-Strand Breaks. Cell 123, 1213-1226, doi:10.1016/j.cell.2005.09.038 (2005).

22 Lou, J. et al. Phasor histone FLIM-FRET microscopy quantifies spatiotemporal rearrangement of chromatin architecture during the DNA damage response. Proceedings of the National Academy of Sciences 116, 7323, doi:10.1073/pnas.1814965116 (2019).

23 Lu, H., Saha, J., Beckmann, P. J., Hendrickson, E. A. \& Davis, A. J. DNA-PKcs promotes chromatin decondensation to facilitate initiation of the DNA damage response. Nucleic Acids Research 47, 9467-9479, doi:10.1093/nar/gkz694 \%J Nucleic Acids Research (2019).

24 Hauer, M. H. \& Gasser, S. M. Chromatin and nucleosome dynamics in DNA damage and repair. 31, 2204-2221, doi:10.1101/gad.307702.117 (2017).

Abrahamsson, S. et al. Fast multicolor 3D imaging using aberration-corrected multifocus microscopy. Nature Methods 10, 60-63, doi:10.1038/nmeth.2277 (2013).

26 Sun, $X$. et al. Development of SNAP-tag fluorogenic probes for wash-free fluorescence imaging. Chembiochem 12, 2217-2226, doi:10.1002/cbic.201100173 (2011).

Toseland, C. P. Fluorescent labeling and modification of proteins. J Chem Biol 6, 85-95, doi:10.1007/s12154-013-0094-5 (2013).

8 Pfeifer, C. R. et al. Constricted migration increases DNA damage and independently represses cell cycle. Molecular Biology of the Cell 29, 19481962, doi:10.1091/mbc.E18-02-0079 (2018).

Cho, S. et al. Mechanosensing by the Lamina Protects against Nuclear Rupture, DNA Damage, and Cell-Cycle Arrest. Developmental Cell 49, 920935.e925, doi:10.1016/j.devcel.2019.04.020 (2019).

30 Nava, M. M. et al. Heterochromatin-Driven Nuclear Softening Protects the Genome against Mechanical Stress-Induced Damage. Cell 181, 800-817 e822, doi:10.1016/j.cell.2020.03.052 (2020).

Xia, Y. et al. Nuclear rupture at sites of high curvature compromises retention of DNA repair factors. The Journal of cell biology 217, 37963808, doi:10.1083/jcb.201711161 (2018).

2 Discher, D. E., Janmey, P. \& Wang, Y.-I. Tissue Cells Feel and Respond to the Stiffness of Their Substrate. Science 310, 1139, doi:10.1126/science.1116995 (2005).

Rehfeldt, F., Engler, A. J., Eckhardt, A., Ahmed, F. \& Discher, D. E. Cell responses to the mechanochemical microenvironment-implications for regenerative medicine and drug delivery. Adv Drug Deliv Rev 59, 1329-1339, doi:10.1016/j.addr.2007.08.007 (2007).

Zemel, A., Rehfeldt, F., Brown, A. E., Discher, D. E. \& Safran, S. A. Optimal matrix rigidity for stress fiber polarization in stem cells. Nat Phys 6, 468473, doi:10.1038/nphys1613 (2010).

Neelam, S. et al. Direct force probe reveals the mechanics of nuclear homeostasis in the mammalian cell. Proceedings of the National Academy of Sciences 112, 5720, doi:10.1073/pnas.1502111112 (2015).

36 Wang, X. et al. Mechanical stability of the cell nucleus - roles played by the cytoskeleton in nuclear deformation and strain recovery. Journal of Cell Science 131, jcs209627, doi:10.1242/jcs.209627 (2018).

7 Alisafaei, F., Jokhun, D. S., Shivashankar, G. V. \& Shenoy, V. B. Regulation of nuclear architecture, mechanics, and nucleocytoplasmic shuttling of epigenetic factors by cell geometric constraints. Proceedings of the National Academy of Sciences 116, 13200, doi:10.1073/pnas.1902035116 (2019).

Swift, J. et al. Nuclear Lamin-A Scales with Tissue Stiffness and Enhances Matrix-Directed Differentiation. Science 341, 1240104, doi:10.1126/science.1240104 (2013).

Sharma, S., Santiskulvong, C., Rao, J., Gimzewski, J. K. \& Dorigo, O. The role of Rho GTPase in cell stiffness and cisplatin resistance in ovarian cancer cells. Integrative Biology 6, 611-617, doi:10.1039/c3ib40246k \%J Integrative Biology (2014). 
bioRxiv preprint doi: https://doi.org/10.1101/2020.07.10.197517; this version posted July 11, 2020. The copyright holder for this preprint (which was not certified by peer review) is the author/funder, who has granted bioRxiv a license to display the preprint in perpetuity. It is made available under aCC-BY-NC-ND 4.0 International license.

40 Raudenska, M. et al. Cisplatin enhances cell stiffness and decreases invasiveness rate in prostate cancer cells by actin accumulation. Scientific Reports 9, 1660, doi:10.1038/s41598018-38199-7 (2019).

41 Kühne, M. et al. A Double-Strand Break Repair Defect in ATM-Deficient Cells Contributes to Radiosensitivity. Cancer Research 64, 500, doi:10.1158/0008-5472.CAN-03-2384 (2004). Riballo, E. et al. A Pathway of Double-Strand Break Rejoining Dependent upon ATM, Artemis, and Proteins Locating to \&\#x3b3;-H2AX Foci. Molecular Cell 16, 715-724, doi:10.1016/j.molcel.2004.10.029 (2004).

43 Murga, M. et al. Global chromatin compaction limits the strength of the DNA damage response. The Journal of cell biology 178, 1101-1108, doi:10.1083/jcb.200704140 (2007). Kocgozlu, L. et al. Selective and uncoupled role of substrate elasticity in the regulation of replication and transcription in epithelial cells. Journal of Cell Science 123, 29, doi:10.1242/jcs.053520 (2010). Klein, E. A. et al. Cell-Cycle Control by Physiological Matrix Elasticity and In Vivo Tissue Stiffening. Current Biology 19, 1511-1518, doi:10.1016/j.cub.2009.07.069 (2009).

46 Mih, J. D., Marinkovic, A., Liu, F., Sharif, A. S. \& Tschumperlin, D. J. Matrix stiffness reverses the effect of actomyosin tension on cell proliferation. Journal of Cell Science 125, 5974, doi:10.1242/jcs.108886 (2012).

$47 \quad$ Aureille, J. et al. Nuclear envelope deformation controls cell cycle progression in response to mechanical force. EMBO reports 20, e48084, doi:10.15252/embr.201948084 (2019).

48 Tajik, A. et al. Transcription upregulation via force-induced direct stretching of chromatin. Nature Materials 15, 1287-1296, doi:10.1038/nmat4729 (2016)

49 Park, S. Mechanical Alteration Associated With Chemotherapeutic Resistance of Breast Cancer Cells. Journal of cancer prevention 23, 87-92, doi:10.15430/JCP.2018.23.2.87 (2018).

50 Liu, H.-C. et al. Characterizing Deformability of Drug Resistant Patient-Derived Acute Lymphoblastic Leukemia (ALL) Cells Using Acoustic Tweezers. Scientific Reports 8, 15708, doi:10.1038/s41598-018-34024-3 (2018).

51 Fili, N. et al. NDP52 activates nuclear myosin VI to enhance RNA polymerase II transcription. Nature Communications 8, 1871, doi:10.1038/s41467017-02050-w (2017).

52 Sbalzarini, I. F. \& Koumoutsakos, P. Feature point tracking and trajectory analysis for video imaging in cell biology. J Struct Biol 151, 182-195, doi:10.1016/j.jsb.2005.06.002 (2005).

53 Aaron, J., Wait, E., DeSantis, M. \& Chew, T. L. Practical Considerations in Particle and Object Tracking and Analysis. Curr Protoc Cell Biol 83, e88, doi:10.1002/cpcb.88 (2019).

54 Engler, A. J., Rehfeldt, F., Sen, S. \& Discher, D. E. in Methods in Cell Biology Vol. 83 521-545 (Academic Press, 2007).

55 Kaliman, S., Jayachandran, C., Rehfeldt, F. \& Smith, A. S. Novel growth regime of MDCK II model tissues on soft substrates. Biophys $J$ 106, L25-28, doi:10.1016/j.bpj.2013.12.056 (2014). 
bioRxiv preprint doi: https://doi.org/10.1101/2020.07.10.197517; this version posted July 11, 2020. The copyright holder for this preprint (which was not certified by peer review) is the author/funder, who has granted bioRxiv a license to display the preprint in perpetuity. It is made available under aCC-BY-NC-ND 4.0 International license.
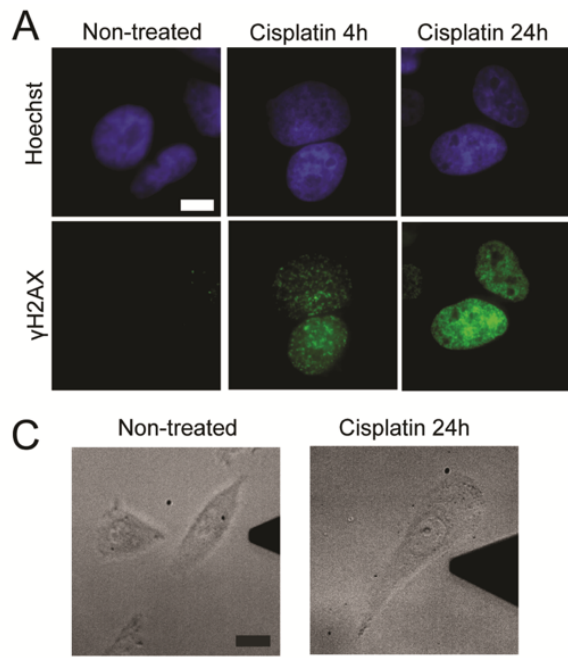

Cisplatin 24h

\section{$\mathrm{E}$}

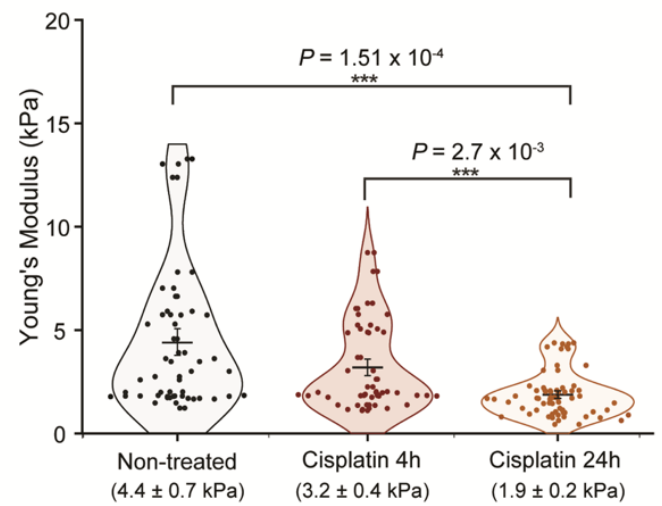

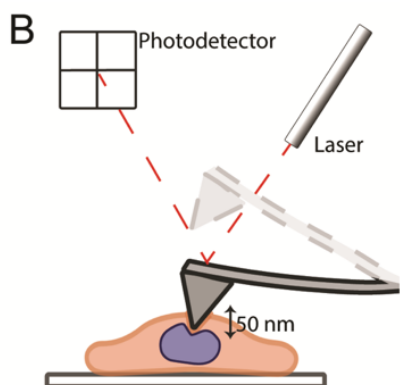

D Non-treated

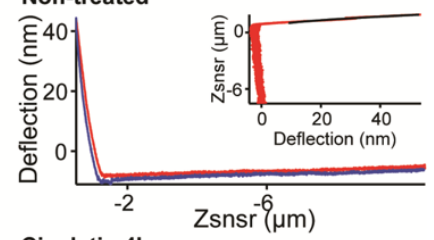

Cisplatin $4 \mathrm{~h}$

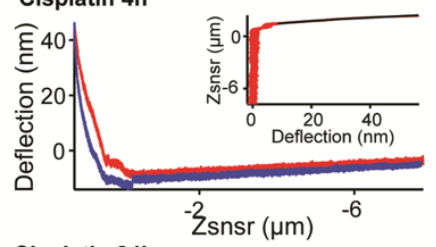

Cisplatin 24h

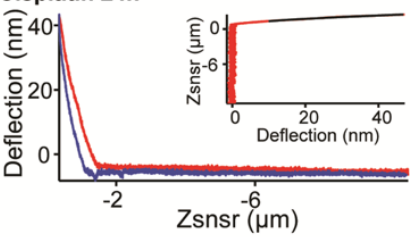

Figure 1 - AFM measurement of cisplatin treated cells. (A) Wide-Field immunofluorescence imaging of $\mathrm{YH} 2 \mathrm{AX}$ (green) in HeLa cells (scale bar $=10 \mu \mathrm{m}$ ). (B) Cartoon depicting AFM measurement. Cells are attached on glass, and a cantilever with a pyramidal tip is used to probe cellular mechanics at a central point above the nucleus. (C) Transmitted light sample images from wide-field microscope coupled to AFM, showing non-treated cells and cells after long cisplatin treatment (24 hours). Scale bar $20 \mu \mathrm{m}$. (D) Representative distance (Zsnsr) versus deflection AFM curves for all three conditions tested are shown, with approach and retraction curves in red and blue, respectively. Curve fitting, shown above curves, was performed using the Hertz model, as described in methods (E) Young's moduli values for non-treated $(n=29)$, cisplatin $4 \mathrm{~h}(n=29)$ and cisplatin $24 \mathrm{~h}(n=34)$ treatments. Each point corresponds to the average value for a cell, calculated from ten measurements. Mean \pm SE are represented in the plot and values are shown below each condition. $p$-values were calculated by a two-tailed t-test, assuming equal variance; ${ }^{* * *} p<0.001$. 
bioRxiv preprint doi: https://doi.org/10.1101/2020.07.10.197517; this version posted July 11, 2020. The copyright holder for this preprint (which was not certified by peer review) is the author/funder, who has granted bioRxiv a license to display the preprint in perpetuity. It is made available under aCC-BY-NC-ND 4.0 International license.

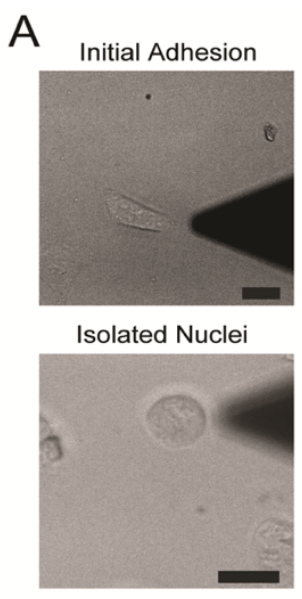

B
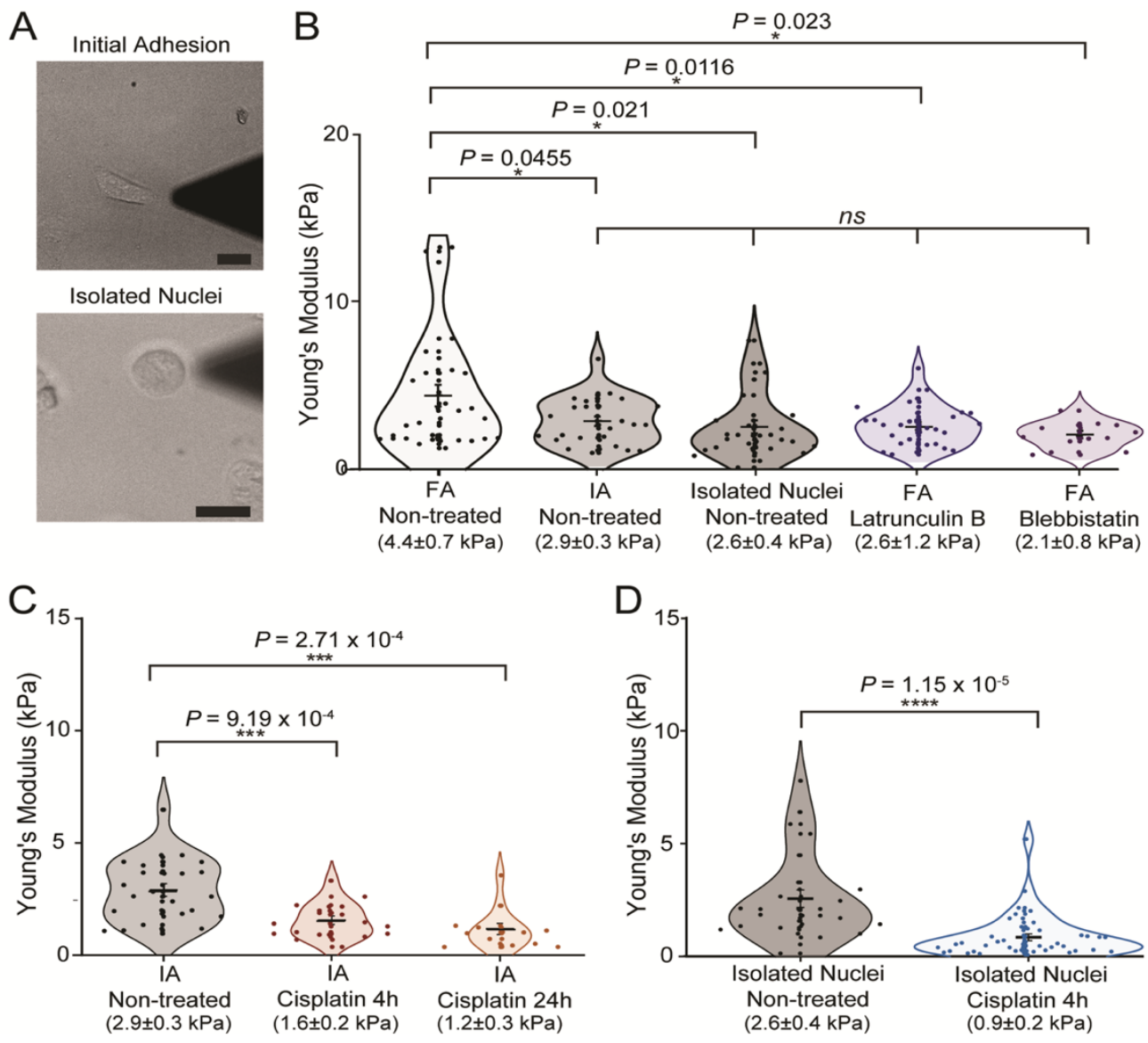

Figure 2 - Initially adhered and isolated nuclei measurements in HeLa cells after DNA damage. (A) Representative transmitted light images from wide-field microscope coupled to AFM, showing initially adhered cells and isolated nuclei. (Scale bar $20 \mu \mathrm{m}$ ) (B) Young's moduli values for comparison between fully adhered cells $(n=29)$, initially-adhered cells $(n=26)$, isolated nuclei $(n=32)$ and after cytoskeleton disruption with drugs LatB $(n=$ 28) and Blebbistatin ( $n=13)$. (C) Young's moduli of initially adhered cells after $4(n=17)$ and 24-hour $(n=13)$ cisplatin treatments. (D) Values for AFM measurements of non-treated isolated nuclei and nuclei isolated after 4hour cisplatin treatment $(n=40)$. Mean values \pm SE are represented in the plot. $p$-values were calculated by twotailed t-test, assuming equal variance; $n s>0.05^{*} p<0.05 ;{ }^{* *} p<0.01 ;{ }^{* * *} p<0.001 ;{ }^{* * * *} p<0.0001$. 
bioRxiv preprint doi: https://doi.org/10.1101/2020.07.10.197517; this version posted July 11, 2020. The copyright holder for this preprint (which was not certified by peer review) is the author/funder, who has granted bioRxiv a license to display the preprint in perpetuity. It is made available under aCC-BY-NC-ND 4.0 International license.

A
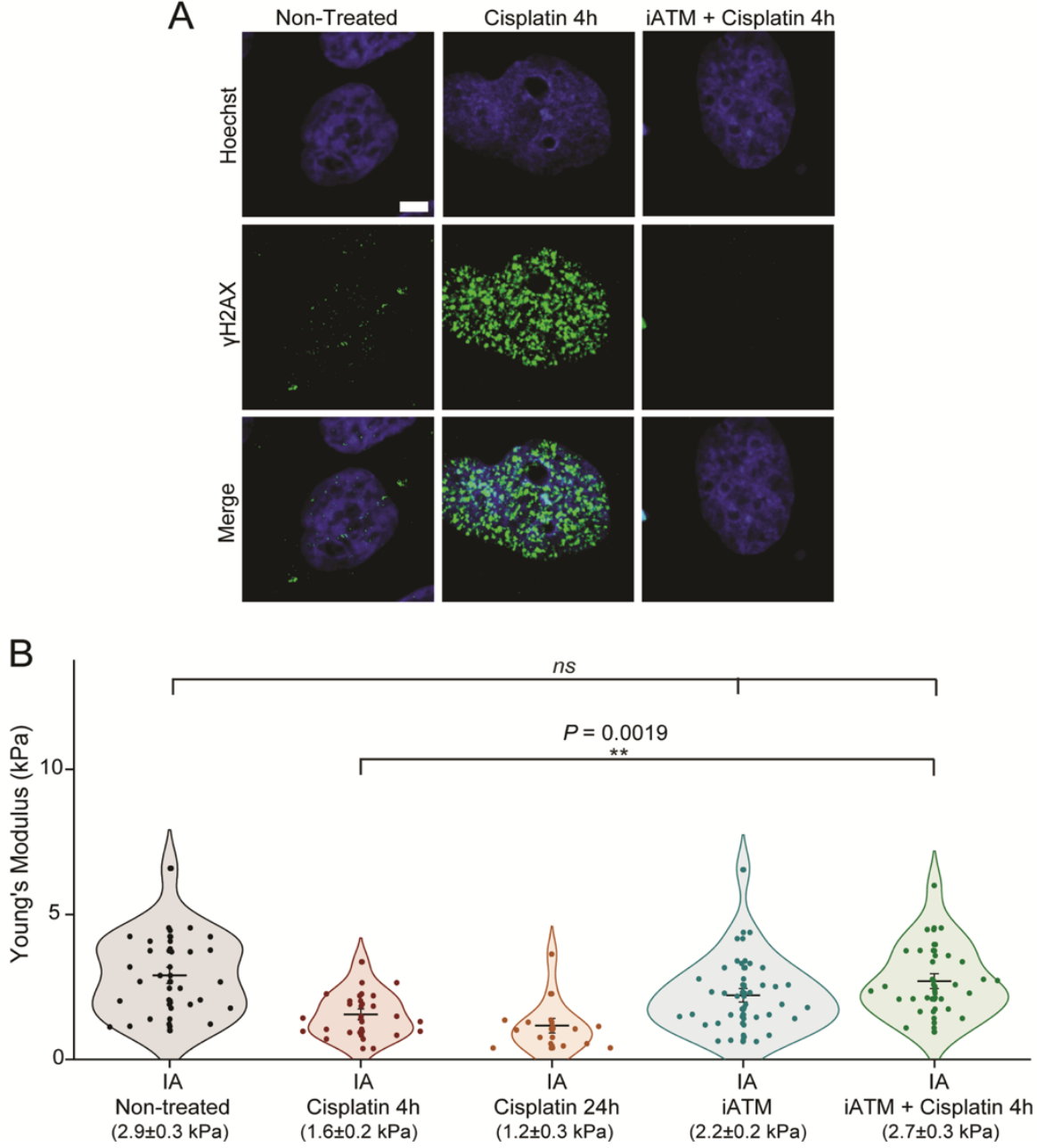

Figure 3 - ATM inhibition impairs nuclear mechanical response to DNA damage. (A)Confocal immunofluorescence imaging of $\mathrm{\gamma H} 2 \mathrm{AX}$ (green), with nuclear stain Hoechst, after cisplatin treatment in the presence or absence of ATM inhibitor (Scale bar $=10 \mu \mathrm{m}$ ). (B) Young's moduli values after short and long cisplatin treatments, and in cells treated with both ATM inhibitor and cisplatin $(n=24)$. Cells treated with only iATM are also shown $(n=31)$. Plot shows mean values \pm SE. $p$-values from two-tailed t-test, assuming equal variance between conditions are also shown ( $\left.n s>0.05 ;{ }^{*} p<0.05 ;{ }^{* *} p<0.01\right)$. 
bioRxiv preprint doi: https://doi.org/10.1101/2020.07.10.197517; this version posted July 11, 2020. The copyright holder for this preprint (which was not certified by peer review) is the author/funder, who has granted bioRxiv a license to display the preprint in perpetuity. It is made available under aCC-BY-NC-ND 4.0 International license.

A
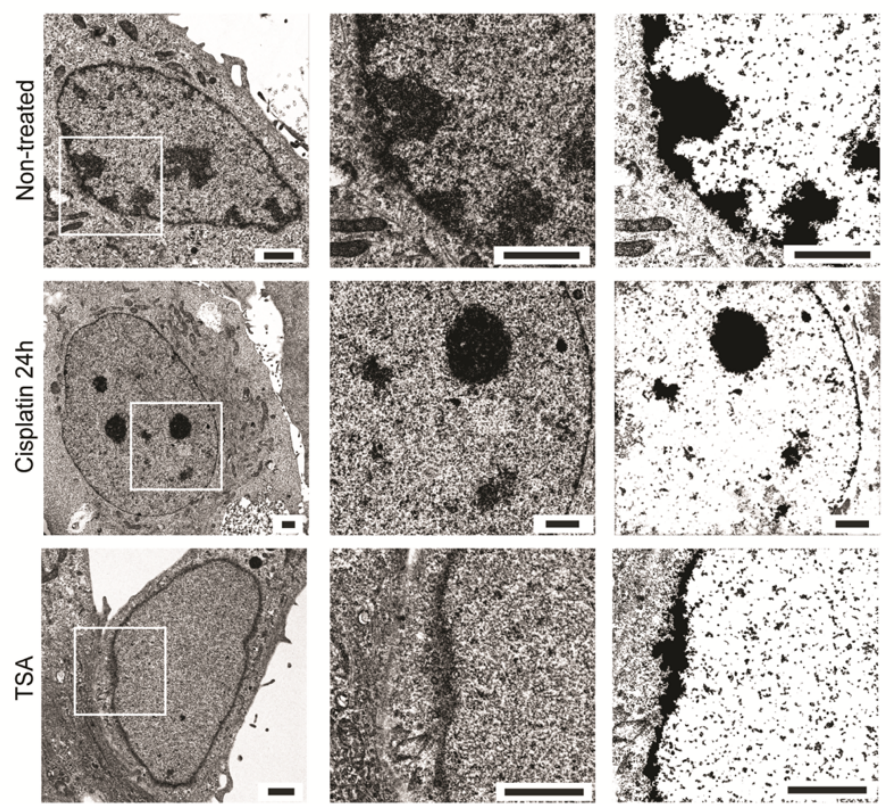

B

C
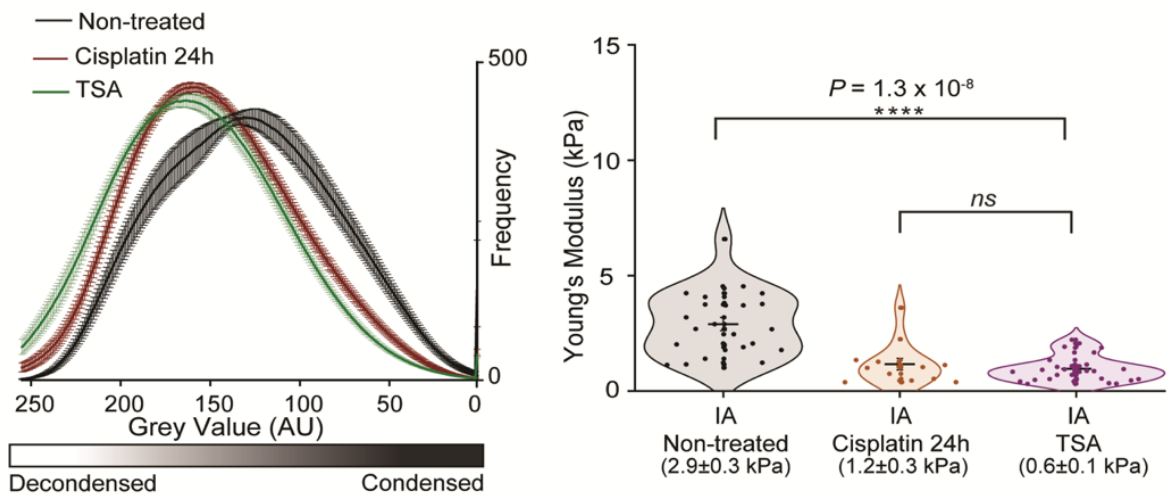

Figure 4 - Electron Microscopy for quantification of chromatin condensation levels. (A) Electron microscopy of HeLa cells after long cisplatin treatment and treatment with deacetylase inhibitor TSA. White squares on left panel represent area selected for detail on middle panel. Threshold images are shown on the right panel (Scale bars $=2 \mu \mathrm{m}$ ). (B) Quantification of dark and light pixels from electron microscopy images inside the nucleus, representing condensed and decondensed chromatin. Values for non-treated cells are in black $(n=21)$, long cisplatin treatment in red $(n=26)$ and TSA $(n=26)$. (C) Young's moduli values of initially adhered cells, comparing non-treated and 24-hour cisplatin treatment with TSA $(n=28)$. For all experiments, the mean values \pm SE are plotted. Statistical differences were calculated using two-tailed t-test, assuming equal variance between conditions and $p$-values are shown $\left(n s>0.05 ;{ }^{*} p<0.05 ;{ }^{* *} p<0.01 ;{ }^{* * *} p<0.001 ;{ }^{* * * *} p<0.0001\right)$. 
bioRxiv preprint doi: https://doi.org/10.1101/2020.07 10.197517; this version posted July 11, 2020. The copyright holder for this preprint (which was not certified by peer review) is the author/funder, who has granted bioRxiv a license to display the preprint in perpetuity. It is made available under aCC-BY-NC-ND 4.0 International license.
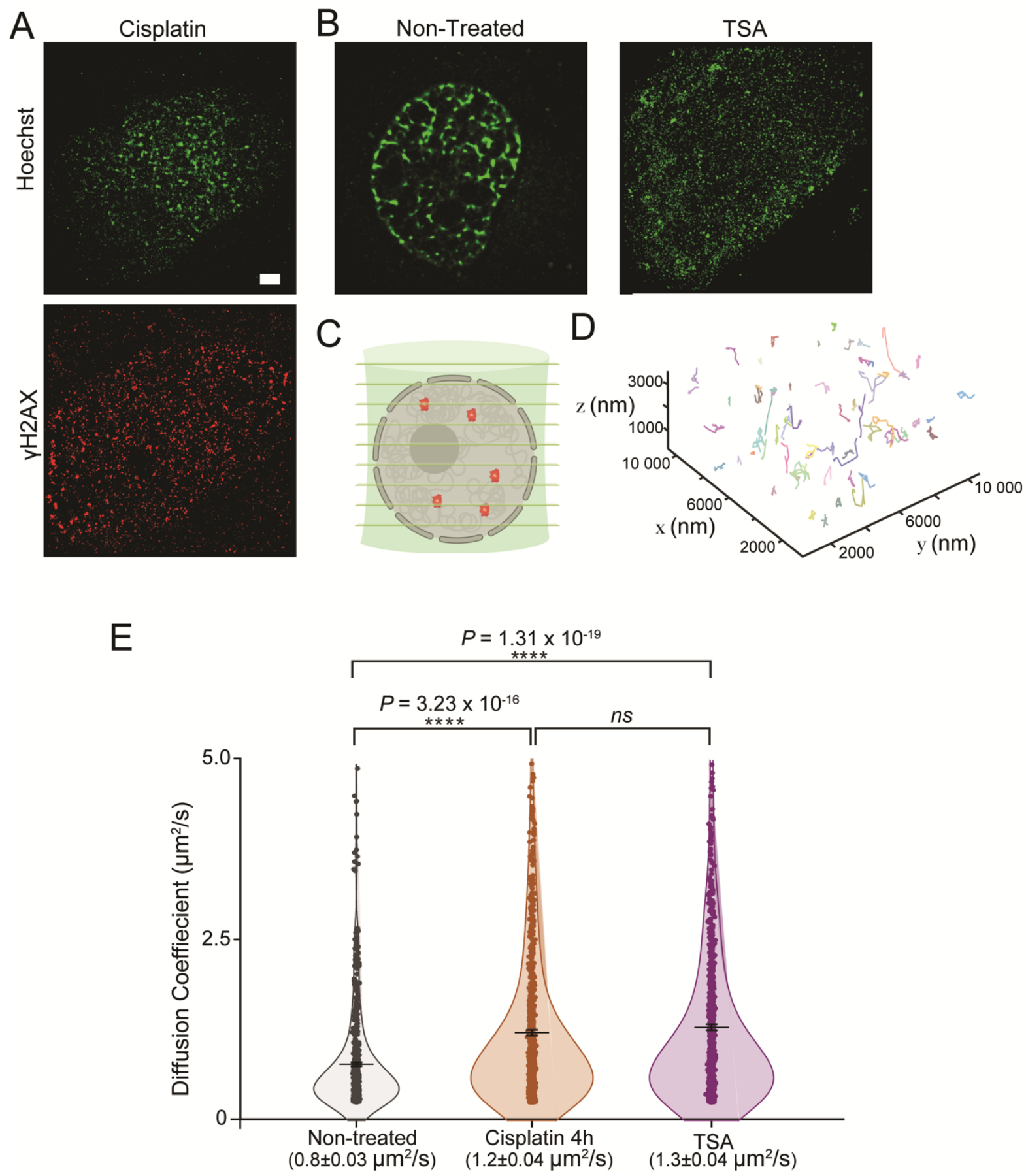

Figure 5 - Impact of DNA damage on chromatin organisation and molecular diffusion in the nucleus. (A) Representative STORM images of chromatin labelled with Hoechst of HeLa cells after cisplatin treatment, with immunolabelling of $\mathrm{yH} 2 \mathrm{AX}$ (red). Scale bar $=2 \mu \mathrm{m}$. (B) STORM images of chromatin in non-treated and TSA treated HeLa cells. (C) Cartoon depicting simultaneous acquisition of nine focal planes using multifocal microscopy for 3D single-molecule tracking of a reporter SNAP-tag. (D) Example of 3D molecule trajectories under normal conditions. (E) Diffusion Coefficients calculated from 3D single-molecule tracking after fitting trajectories assuming an anomalous diffusion model. Plot shows mean values \pm SE. $p$-values were calculated with a two-tailed t-test, assuming equal variance (ns>0.05; $\left.{ }^{*} p<0.05 ;{ }^{* *} p<0.01 ;{ }^{* * *} p<0.001 ;{ }^{* * *} p<0.0001\right)$. 
bioRxiv preprint doi: https://doi.org/10.1101/2020.07.10.197517; this version posted July 11, 2020. The copyright holder for this preprint (which was not certified by peer review) is the author/funder, who has granted bioRxiv a license to display the preprint in perpetuity. It is made available under aCC-BY-NC-ND 4.0 International license.

A
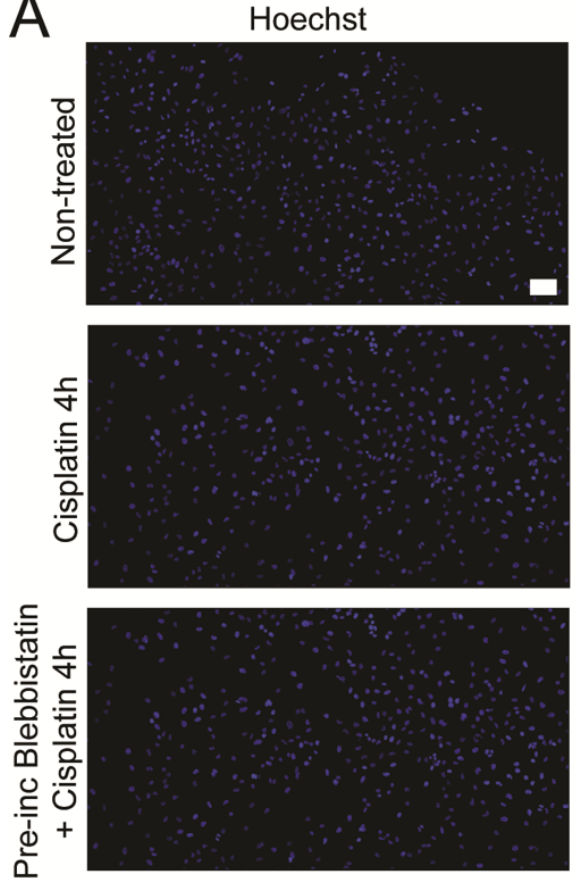

Rhodamine Phalloidin
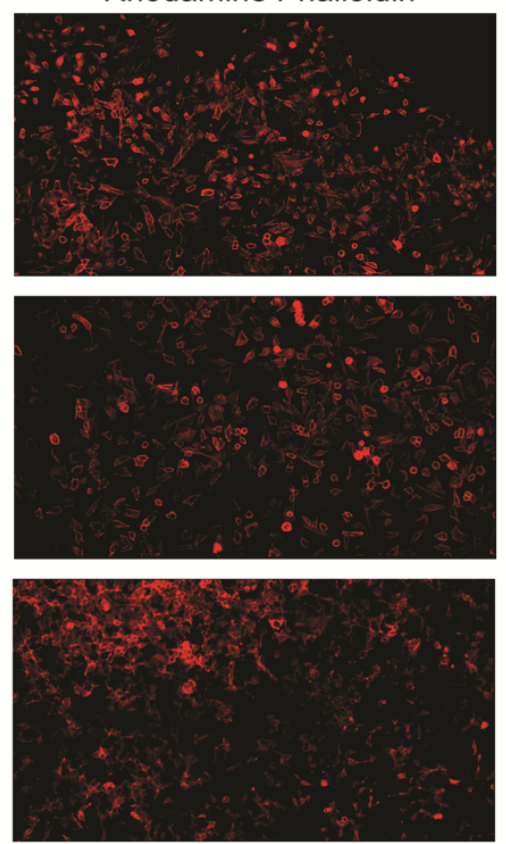

$\mathrm{YH} 2 \mathrm{AX}$
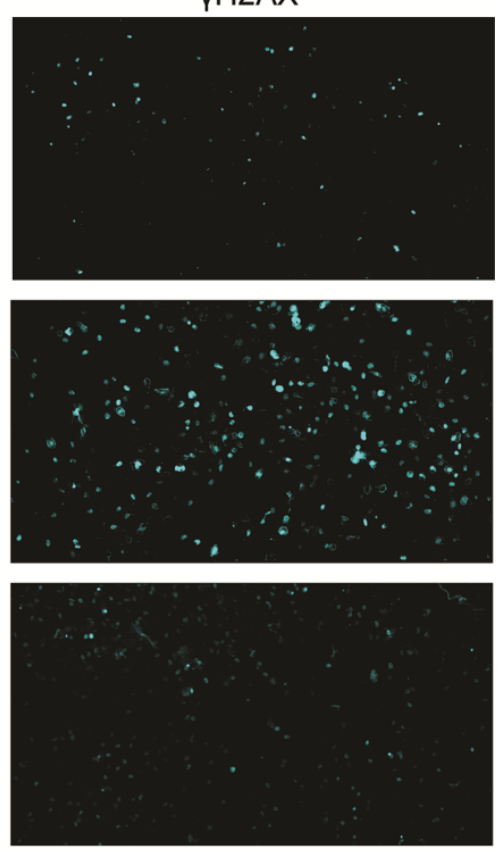

B

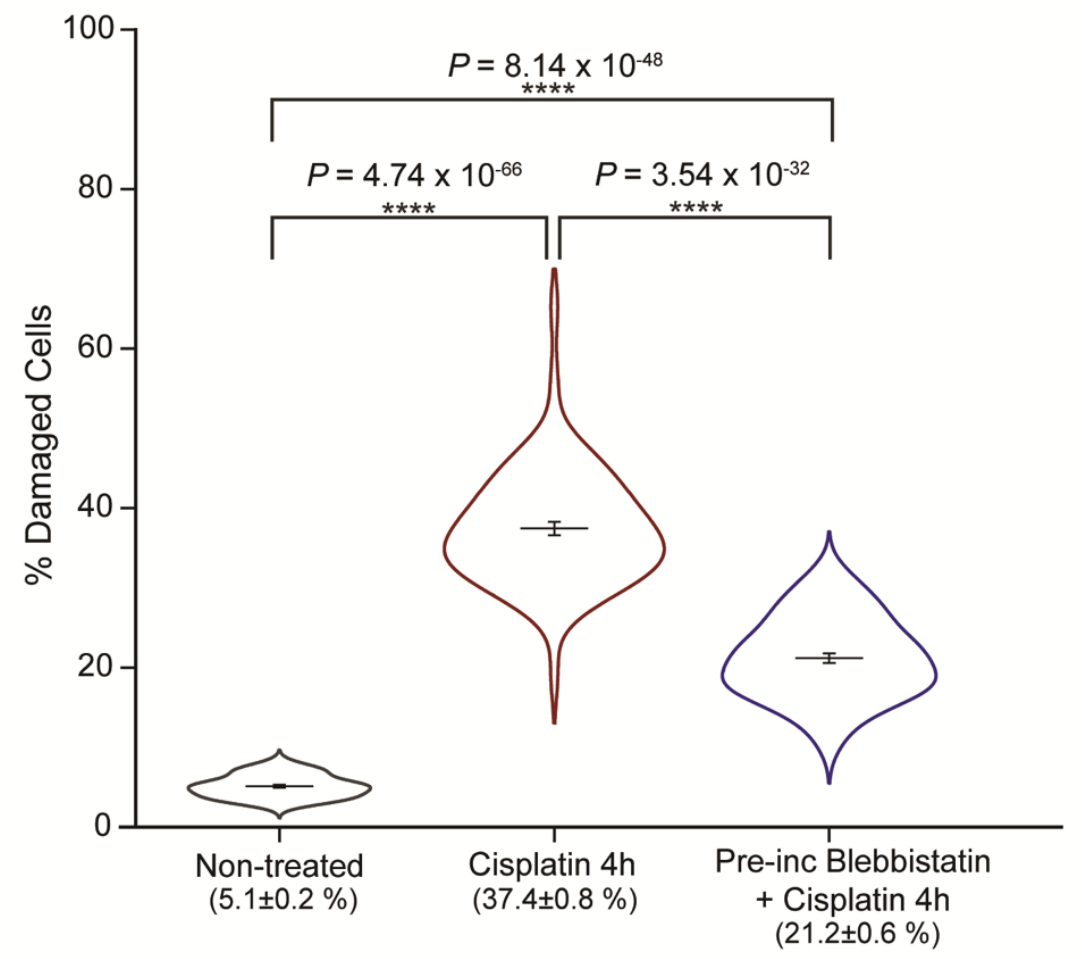

Figure 6 - Impact of Blebbistatin on yH2AX signalling in HeLa cells. (A) Representative images from highcontent screening of HeLa cells treated with cisplatin in the presence or absence of Blebbistatin. Nuclear staining with Hoechst and Actin labelling with Rhodamine phalloidin are shown in addition to immunofluorescent labelling of $\mathrm{yH} 2 \mathrm{AX}$. Scale bar $=100 \mu \mathrm{m}$. (B) Levels of damage in HeLa cells from high-content screening, calculated as percentage of nuclei displaying $\mathrm{yH} 2 \mathrm{AX}$ signalling. $P$ values are shown between non-treated cells $(n=58$, representing 51233 cells), 4-hour cisplatin treatment ( $n=70$, representing 63422 cells) and combined Blebbistatin and cisplatin treatment ( $n=68$, representing 57274 cells). For all conditions, mean values \pm SE are plotted. Twotailed t-test, assuming equal variance, was used for $p$-value calculation (ns>0.05; ${ }^{*} p<0.05$; ${ }^{* *} p<0.01 ;{ }^{* * *} p<0.001$; $\left.{ }^{* * \star *} p<0.0001\right)$. 
bioRxiv preprint doi: https://doi.org/10.1101/2020.07.10.197517; this version posted July 11, 2020. The copyright holder for this preprint (which was not certified by peer review) is the author/funder, who has granted bioRxiv a license to display the preprint in perpetuity. It is made available under aCC-BY-NC-ND 4.0 International license.

A
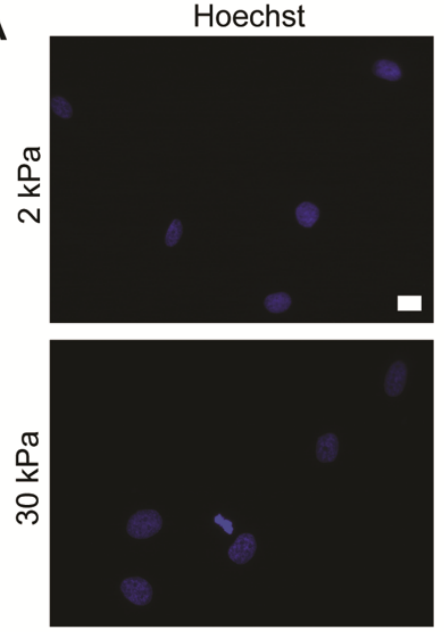

B

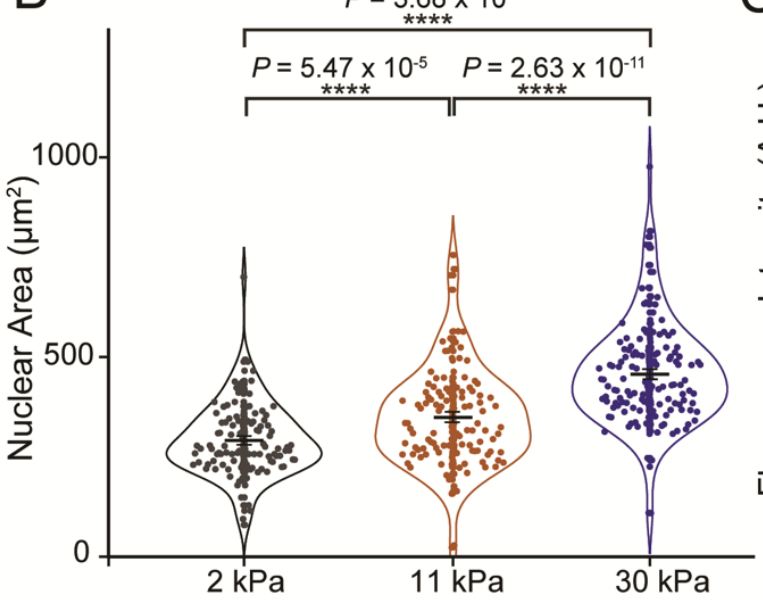

$\left(291.0 \pm 8.5 \mu \mathrm{m}^{2}\right) \quad\left(349.0 \pm 11.0 \mu \mathrm{m}^{2}\right)\left(456.8 \pm 10.8 \mu \mathrm{m}^{2}\right)$

Gel Stiffness
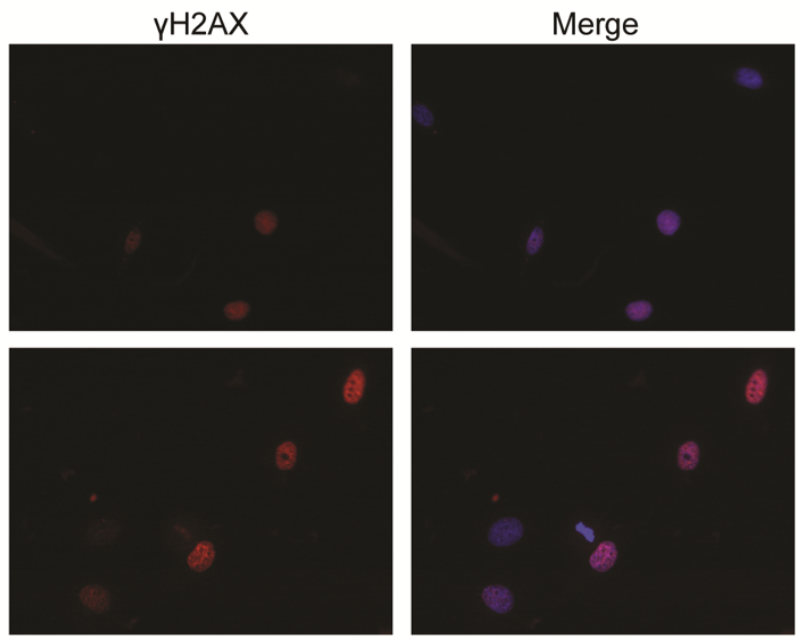

C
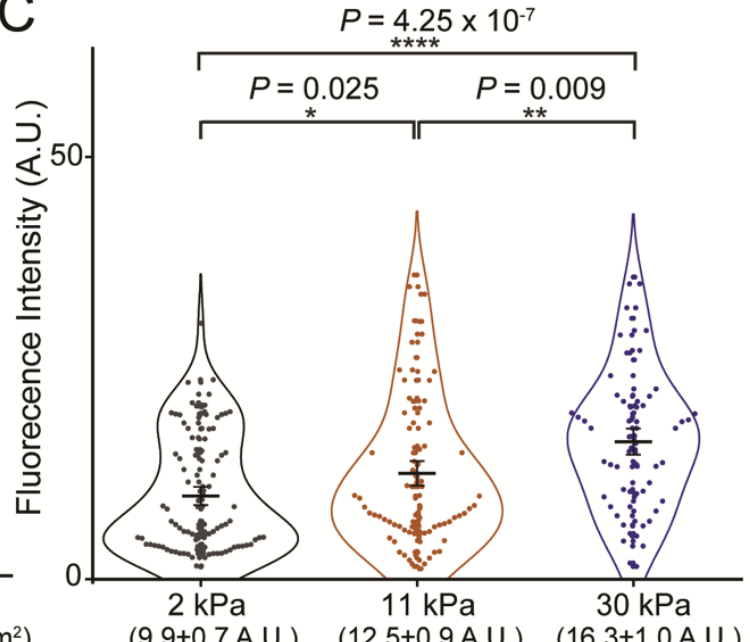

$(9.9 \pm 0.7$ A.U.)

Gel Stiffness

Figure 7 - Impact of nuclear relaxation on yH2AX signalling in HeLa cells. (A) Representative Wide-field images of HeLa cells growing on gels of different stiffness - 2 and $30 \mathrm{kPa}-$ after cisplatin treatment. Immunofluorescent labelling of $\mathrm{yH} 2 \mathrm{AX}$ is shown in red, with nuclear stain Hoechst in blue. (Scale bar $=20 \mu \mathrm{m})$. (B) Nuclear area of cells on different surfaces $-2 \mathrm{kPa}(n=111), 11 \mathrm{kPa}(n=121)$ and $30 \mathrm{kPa}(n=139)$. $P$ values are shown. (C) Fluorescence intensity of red channel ( $\mathrm{HH} 2 \mathrm{AX})$ within the nucleus of cells grown on surfaces of different stiffness $-2 \mathrm{kPa}(n=90), 11 \mathrm{kPa}(n=79)$ and $30 \mathrm{kPa}(n=61)$. In all cases, mean values \pm SE are shown. Twotailed t-test, assuming equal variance, was used for statistical calculations and $p$-values are shown ( $n s>0.05$; $\left.{ }^{*} p<0.05 ;{ }^{* *} p<0.01 ;{ }^{* * *} p<0.001 ;{ }^{* * *} p<0.0001\right)$. 